\title{
To PRESERVE THE MOUNTAINS AND THE COMMUNITY: \\ INDIGENOUS ECOTOURISM AS A Sustainable DeVElopment StRATEGY
}

\author{
MAGGIE GRIEVES \\ University of Maryland, Baltimore County \\ MARINA ADLER \\ University of Maryland, Baltimore County \\ ROBIN KING \\ University of Maryland, Baltimore County
}

\begin{abstract}
This research explores the role of community control, various community characteristics, and inter-community coalitions in facilitating the viability of ecotourism projects. The goal is to generate a model that can guide future research efforts about ecotourism projects in Indigenous communities. Results from two communities in Oaxaca, Mexico show that in addition to community control, factors increasing accessibility (infrastructure), visibility (public relations) and connectivity (collaboration with other organizations) are important for project success. Community controlled ecotourism may have a positive impact on the community itself, including resource
\end{abstract}

\footnotetext{
Maggie Grieves is an adjunct in the Department of Sociology and Anthropology at the University of Maryland, Baltimore County (UMBC). She teaches American Indian culture and social theory. Marina Adler is an associate professor in Sociology at UMBC. Her research addresses cross-national issues related to gender, class, and ethnicity. Robin King holds an MA from the Department of Modern Languages and Linguistics at UMBC. Contact can be directed to grieves1@umbc.edu.
} 
development, decreased migration, and control over cultural and environmental exploitation.

\section{Introduction}

With increased international awareness of the need to preserve the environment, sustainable development is becoming an important focus for transnational, nongovernmental organizations (NGOs) in developing countries. The Brundtland Report, written by the World Commission on Environment and Development (WCED), and published as Our Common Future, defines sustainable development as "development that meets the needs of the present without compromising the ability of future generations to meet their own needs" (1987:43). In this process the "essential needs" of the poor are to be given precedence in development projects, and "both economic and social development must be redefined in terms of sustainability..." (WCED 1987:43). Although commonly accepted in development literature, these guidelines are not specific enough to direct and implement sustainable development policies, especially within the context of marginalized indigenous communities.

While environmental preservation and poverty elimination remain the cornerstones of sustainable development, throughout the past two decades an increasing emphasis has been placed on local community participation in and community control of sustainable development projects. More recent projects often focus on ecotourism, or sustainable tourism, as both ecologically and socio-culturally sound strategies to sustain indigenous, communityowned natural resources. These ecotourism projects strive to include mechanisms that both ensure the profits generated by ecotourism primarily benefit the indigenous community rather than outside agencies, and also build a community's capacity to autonomously create additional revenue-generating, sustainable development projects. As such, the partnerships between indigenous communities and outside organizations are often characterized by tensions and power imbalances caused by resource differences, clashing values, and incompatible practices (Mawdsley et al. 2002; Roberts, Jones, and Froehling 2005).

Ecotourism refers to programs that have less of a negative environmental impact compared with traditional forms of tourism 
(Stronza, 2008). Although ecotourism is not specifically mentioned in the Brundtland Report as a form of sustainable development, it similarly involves the concerted participation of local communities, state agencies, transnational funding agencies, and international tourists. Community-managed ecotourism projects provide an opportunity to examine how sustainable development ideals translate into practice, and how local interests intersect with international interests. In addition, development processes may support or challenge indigenous traditions via potentially contradictory project objectives. Advocates for ecotourism projects seek to avoid the economic and cultural exploitation inherent in international mass tourism. Nevertheless, revenues generated through ecotourism may primarily benefit individuals outside indigenous communities.

Within the context of community control and decision-making, the focus of ecotourism is expanding from environmental protection to a greater emphasis on community autonomy. Increasingly, ecotourism projects struggle with how to foster genuine community involvement in planning and decision-making, which conflicts with the management ideology of many international funding agencies. Western management styles are characterized by hierarchical authority structures and project oversight designed to maximize efficiency (Roberts et al. 2005). This "managerialism" approach promotes project oversight based on hierarchical models, which often conflict with the horizontal decision-making style of indigenous community assemblies. In contrast to managerialism, indigenous consensus-based decisionmaking styles provide a participatory mechanism that allows communities to retain control of project oversight and to distribute resultant profits equitably among community members. At the same time, complete rejection of alliances with outside influences can lead to the failure of projects because of isolation and a lack of resources.

Some indigenous communities in the state of Oaxaca, Mexico, are initiating community-controlled productive projects, including ecotourism projects, as a means of economic development. Their goals include community self-sufficiency, environmental protection, cultural preservation, political empowerment, and reduced migration out of rural communities. Our research focuses 
on two ecotourism projects in communities in Oaxaca as possible means of sustainable development and community empowerment, and explores which community characteristics and dynamics facilitate the viability of ecotourism projects. Specifically, this research examines the roles of community autonomy and community control in the success of ecotourism projects as means of sustainable community livelihood. The definition of what constitutes success and viability in the context of ecotourism projects is complex. For example, defining success by the number of tourists is problematic because, by this standard, projects could be too successful in the sense that the burden of hosting tourists could outweigh benefits to the community. We consider project viability in the context of community self-sufficiency and wellbeing, as well as community members' perceptions of project success. We argue that community control of projects through participatory governance is essential to success, while community autonomy must be balanced with connections to other communities and organizations. In addressing these issues, we propose a model to guide future research efforts and policies about ecotourism projects in indigenous communities to increase empowerment and sustainable livelihoods.

\section{Literature Review}

Definitions of what constitutes "genuine" ecotourism remain contested. However, a working definition first proposed by Héctor Ceballos-Lascuráin in 1983 was adopted with modifications by the International Union for Conservation of Nature (IUCN) in 1996. The IUCN defines ecotourism as "environmentally responsible travel to natural areas, in order to enjoy and appreciate nature (and accompanying cultural features, both past and present) that promote conservation, have a low visitor impact and provide for beneficially active socio-economic involvement of local peoples" (Ceballos-Lascuráin 1996:1). A great deal of literature focuses on the sustainability of tourism without necessarily advocating for the level of community control and local economic benefit inherent to ecotourism (Gössling, Hall, and Weaver 2009; Ritchie and Crouch 2003). As exemplified in the IUCN's definition, the concept of ecotourism originates in and combines aspects of both sustainable nature tourism and cultural tourism, but adds the requirements of 
social and economic benefits to local peoples. However, the IUCN's definition lacks any reference to local participation in decision-making processes related to project implementation and management, and in this aspect it remains incomplete. Other researchers have attempted to refine this deffintion. For example, Honey includes political empowerment in her definition of ecotourism (2008), while Zeppel further clarifies that the "key aspects of indigenous ecotourism include a nature-based product, indigenous ownership and the presentation of indigenous environmental and cultural knowledge ${ }^{1,}$ (2006:11).

Ecotourism continues to grow as an industry, and ecotourism projects exist in every region of the world (Zeppel 2006). Proposed as a panacea for "underdevelopment" (World Ecotourism Summit 2002), much of the literature on ecotourism focuses on the environmental and cultural impacts of increased tourism in natural areas. For instance, Cerina (2008) provides a complex statistical tool designed to predict the ideal balance of environmental impact, degradation abatement, and tourist density, and suggests that these three factors must be in equilibrium for ecotourism to be considered a success. He concludes that the abatement of negative environmental effects is easier to achieve among tourists seeking a "low-tourist density" experience, relative to traditional "masstourism." Cerina's research concurs with the findings of Rinzin, Vermeulen, and Glassbergen's study of ecotourism initiatives in Bhutan, which indicate tourism development has the least negative environmental and cultural impact when it pursues a strategy that provides high value for the community while causing low impact on the daily lives of residents (2007). However, the models of ecotourism offered by Cerina (2008) and Rinzin et al. (2007) presuppose a high degree of national government control of tourism development, rather than a locally generated movement to achieve the goals of sustainability. It remains unclear to what extent local communities achieve economic benefits or empowerment from these state-operated policy initiatives.

\footnotetext{
${ }^{1}$ Ethnotourism tends to make reproduction and commodification of specific aspects of local culture the focus of the tourist experience (Yang 2011), whereas ecotourism, although potentially containing aspects of ethnotourism, focuses primarily on the sustainable ecological impacts of tourist activities.
} 
One appeal of ecotourism lies in its goal to mitigate burdens on the environment and local cultures resulting from increased tourism to an area. Some researchers caution that the negative impact of tourists on the environment and indigenous cultures is inevitable (Place 1998), while other researchers suggest that endemically derived solutions can mitigate the most egregious negative impacts from tourism if local communities are able to exercise control over tourists' activities (Zeppel 1998). Comparisons of ecotourism and traditional mass tourism suggest that tourism in any form potentially compromises the cultural integrity of targeted indigenous communities (Place 1998).

In response to such concerns, the Québec Declaration on Ecotourism, a product of the 2002 World Ecotourism Summit, makes specific recommendations to indigenous communities for dealing with tourism programs. For example, the declaration recommends that a community develop a strategic plan to ensure collective benefits, "including human, physical, financial, and social capital development, and improved access to technical information" (World Ecotourism Summit 2002:2). Furthermore, communities should "strengthen, nurture and encourage the community's ability to maintain and use traditional skills that are relevant to ecotourism, particularly home-based arts and crafts, agricultural produce, traditional housing and landscaping that use local natural resources in a sustainable manner" (World Ecotourism Summit 2002:2). The summit report also called on the World Summit on Sustainable Development to more fully apply the principles of sustainable development to tourism, but cautioned that sustainable tourism must include participatory mechanisms to be considered ecotourism (World Ecotourism Summit 2002). In Mexico, much of the literature on ecotourism focuses on reforestation projects on the coastline (Momsen 2002; Zeppel 2006). These projects have been controlled by large hotels and have not emphasized the participatory components of ecotourism's ideology. In the state of Oaxaca, ecotourism programs initiated by large hotels on the seashore to reforest depleted areas near large luxury resorts do not inherently provide any mechanisms for community control or benefit (Zeppel 2006). However, in the mountainous interior of Oaxaca there is a growing movement for community-controlled ecotourism (Zeppel 2006). 


\section{Community Control of Ecotourism Projects}

Community control of indigenous ecotourism is vital for maintaining sustainability and mitigating negative tourist impact, two indicators of successful ecotourism (Zeppel 1998). Community control of and participation in ecotourism projects increases the social capacity to initiate additional productive projects (Cater 1994). Such community control, although acknowledged by international funding agencies in the sustainable development arena, is often lacking as projects are carried out with the managerial and organizational styles of international NGOs. As De Frece and Poole (2008) show, when international funding agencies do not take into account local cultures, value systems, and decision-making styles, they are unlikely to propose productive projects that will be embraced by the targeted communities. Alternative development models to managerialism include community-level, horizontally oriented oversight processes, such as that practiced in the campesino a campesino (farmer to farmer) approach. This sustainable agricultural movement promotes grassroots development, whereby productive projects in one village are implemented by neighboring villages after project success has been observed directly (Holt-Gimenez 2006).

Community control not only ensures local commitment to the success of a project, but also helps counter the potential "profit leakage" to stakeholders outside the community, a common problem in the ecotourism industry (Place 1998). However, profit leakage to airlines and other "nonecological corporate stakeholders in the tourism industry is beyond the control of communities. Although airlines and other international travel corporations will continue to benefit from ecotourism, the primary objective is that the money spent by tourists for tours, accommodations, and other amenities and attractions accrues to the visited community and primarily benefits community members and their environment. Excluding local populations from project planning disadvantages them not only in terms of the specific tourism project, but also in their ability to implement other forms of community development (Cater 1994).

As with all attempts at sustainable development, ecotourism can be implemented in multiple ways, some of which may not provide for the economic benefit of local communities. In Costa 
Rica, a park-based nature tourism project supported by significant outside investment and government policy did not promote local entrepreneurship (Place 1998). This project had an adverse impact on local economies because residents did not retain control of the projects and were marginalized by larger tourism operators. Place found that "The pace of outside investment is not allowing the villagers the luxury of time to accumulate their own capital to invest in tourist facilities and services" (1998:113). This problem can be mitigated by including community control and decisionmaking, which are key aspects of successful ecotourism: "The debate is currently not whether local communities should be involved in the development of [eco-] tourism to their areas, but how they should be involved" (Stronza 2008:4).

Sustainable forestry projects can contribute to the success of ecotourism projects. Sustainable forestry, defined as forestry management in accordance with the principles of sustainable development (United Nations 1992), supports ecotourism by maintaining the health and beauty of forests and other natural resources. In some communities, sustainable forestry projects provide a model of how indigenous communities can put participatory management and communal profit-sharing into practice (Antinori and Rausser 2006). In community-managed, commercial forestry production, "the community may form a commercial corporation (for example, a sociedad...). Each individual member of the community is a socio - the term for a part-owner, partner, or shareholder in a labor-managed firm-yet, the shares are not defined nor traded" (Antinori and Rausser 2006:515). Ecotourism projects designed as sociedades can potentially increase the economic benefits to all community members while the community oversight mechanisms inherent to this approach help ensure continued community control of projects.

An analysis of the relationship between community characteristics and the viability of ecotourism projects must consider the local context. The next section provides background information on the state of Oaxaca and the key features of Oaxacan indigenous communities. Of particular interest to our questions about community control are unique local participatory governance structures in these communities. 
Table 1. Oaxaca State Demographic Information

\begin{tabular}{lc}
\hline Municipalities & 570 \\
Population & $3,506,821$ \\
Indigenous-Speaking & $31 \%$ \\
Reside in Indigenous Households & $42 \%$ \\
Employed in Agricultural Sector & $37 \%$ \\
Reside in Rural Areas & \\
$\quad$ Oaxaca State & $53 \%$ \\
$\quad$ All of Mexico & $24 \%$ \\
Population Density & \\
$\quad$ Oaxaca State & \\
$\quad$ All of Mexico & 28 people $/ \mathrm{km}^{2}$ \\
\hline
\end{tabular}

Source: INEGI 2005a, 2005b

\section{Characteristics of Indigenous Communities in Oaxaca}

The state of Oaxaca is located in Southern Mexico, reaching from the Pacific coast to the mountainous region of the Sierra Norte. Oaxaca contains 570 distinct municipalities (Table 1). Of the 3.5 million inhabitants, 31 percent speak an indigenous language, and 42 percent live in a household in which an indigenous language is spoken. The official government practice of using language to indicate indigeneity leads to an underreporting of the number of people who identify as indigenous; according to estimates provided by Mexico's National Institute of Statistics and Geography (INEGI) about two thirds of all Oaxacans are indigenous. Alongside Chiapas, this represents the highest proportion of indigenous people in a Mexican state. Residents employed in the agricultural sector make up 37 percent of the populace, while 53 percent of the population lives in rural areas. This is more than twice the proportion of rural residents for Mexico as a whole (24 percent). The average population density of Oaxaca is 38 people per square kilometer, compared with the national average of 53 people per square kilometer (INEGI 2005a; INEGI 2005b).

Oaxaca is the second poorest and least developed state in Mexico. In 1996, the passage of the North American Free Trade Agreement ended Mexico's farm subsidies, which drove many small farmers off the land because they could no longer compete 
with U.S. agribusiness on prices for corn and other commodities (Bacon 2004). The majority of migrants to the northern border region and to the U.S. originate from Oaxaca (Bacon 2004). This outmigration has turned many communities into ghost towns, as most residents of working age have left, leaving only the young and old, and those working in the tourist sector producing arts and crafts.

The indigenous pueblos (simultaneously references a people and their communities) or comunidades (communities) in Oaxaca have unique features that may affect participation in and success of sustainable development initiatives. The communities emphasize collective responsibility and mutual obligation over individual rights (Esteva 2006), which is reflected in their consensus-based governance style, referred to as usos y costumbres (uses and customs), and the traditional system of community reciprocity, called cargo. According to Adler (2012), communal councils decide in assemblies about which community-owned projects to start, who will be involved in project activities, and how to manage the enterprises. They also decide to what degree the community should retain its autonomy or engage in ventures with outside organizations or other communities.

Since the late 1990s, the Mexican government has allowed indigenous communities the option of limited self-governance at the submunicipal level through the practices of Usos y Costumbres. The state of Oaxaca has more communities governed through Usos $y$ Costumbres than any other state in Mexico:

Oaxaca stands out as the Mexican state whose laws have gone the furthest towards recognizing indigenous rights to selfgovernance. Municipalities are allowed to decide whether to govern themselves through partisan balloting or through diverse forms of customary law. For more than a decade, 418 of Oaxaca's 570 municipalities have been governed by nonWestern community decision-making and do not require the intermediation of political parties. (Fox 2007:535)

The system of cargo supports the functioning of Usos $y$ Costumbres because it is "a system of rotating civic and religious responsibilities among registered community members, based on merit accumulated by service in a rising hierarchy of civic 
positions" (Antinori and Rausser 2006:515). The cargo system obliges community members to perform unpaid work that benefits the entire community.

The concept of community is itself a contested term that often has different meanings depending on a speaker's frame of reference. Champagne notes how Western and indigenous North American conceptualizations of community differ:

The decentralized, consensual character of tribal political and social processes are very important to understand when discussing conceptions like community...Indian communities are not a given, as is often implied in the Western interpretation of 'community,' but are possible only through consent among potentially participant local groups. This consensual socialpolitical-cultural community of Indian groups is possible because of the economic, kinship, and political autonomy of most local Indian entities. (2010: 2)

In the context of Mexican indigenous groups, community is realized at the village level and composed of those who participate in local cargo systems and Usos y Costumbres within a specifically limited geographical area.

The practices of Usos y Costumbres and cargo are crucial in understanding the operation of ecotourism projects in Oaxacan indigenous communities. Participatory democracy, consensus decision-making, and the system of mutual obligations and responsibilities for the wellbeing of the community will influence the viability of a tourism project. In Oaxaca, depending on the community's focus on autonomy, multiple stakeholders can contribute to the implementation of ecotourism projects. While the communities provide labor, cultural assets, and the natural environment, local grassroots organizations often provide a framework that promotes sustainable development, expertise with program development, and training in program implementation. Small amounts of seed money are also provided by the Mexican government for programs that promote ecotourism development and reforestation projects. Past partnerships with larger NGOs and the Mexican government have often ignored local needs, conditions, and cultures, and have reduced community autonomy (Adler 2012). Indigenous communities have become increasingly 
suspicious of partnering with NGOs from the United States because of negative consequences from outside influences, such as increased individualism, profit motivation, loss of internal markets, and compromised ethnic identities (Adler 2012; Mawdsley et al. 2002; Roberts et al. 2005). More recently, organizational alliances, particularly those at the grassroots level, are recognizing local voices aiming to preserve indigenous traditions in order to create resilient communities and honor their cultural and natural heritages.

\section{Methodology and Findings}

\section{Methodology}

This exploratory research was part of a larger project investigating community involvement in sustainable development projects in Oaxaca. It utilized qualitative data collection, including project document review, semistructured interviews with key stakeholders, and participant observation in the communities, to assess the experiences of two indigenous communities with ecotourism project development. The goal was to build a conceptual model describing the processes that increase the success of ecotourism projects in indigenous communities.

The research was conducted in two communities in the mountainous interior of Oaxaca in the summer months of 2008. One community had a successful ecotourism project, while the other community's ecotourism project was in the initial stages of design. We selected these communities because they were indigenous, governed by Usos y Costumbres, and situated in a similarly appealing natural terrain suited to ecotourism development. We gained entrance to one community through their ecotourism office in Oaxaca City; the other community required that we be escorted there by someone already known to them, to be introduced to the community leaders before we were allowed to stay. Respondents were chosen through convenience sampling in terms of their expertise as participants in their community's tourism projects. We conducted 11 interviews with community members, including those directly involved in ecotourism projects and those indirectly involved, such as restaurant owners, shop keepers, and other community members encountered in the course 
of the research project. We also interviewed 19 staff members from development NGOs that were active in the region.

The interviews varied in length from one to three hours. Two note-takers recorded respondents' answers, and the two resultant transcripts were later cross-referenced to ensure reliability and completeness. The interviews were conducted in Spanish with simultaneous English translation, and verbal consent was obtained from each interview participant. The interviews consisted of openended questions regarding respondents' assessments of the projects (e.g., goals, successes, problems, decision-making, and work assignments), and various characteristics of the projects (e.g., history, size, funding, alliances, and operations). The transcriptions were examined for statements about respondents' perceptions of the nature and success of the projects, as well as the degree the communities felt in control. Any documentation provided by the community, such as pamphlets, calendars, and mission statements, offered general information about the projects. Participant observation of the ecotourism projects provided the context for the interview data. We participated in events and activities available to tourists in the communities, including booking trips, taking guided hikes, sleeping in community accommodations, and interacting with community members.

One of the limitations of our research was that it only included two communities. However, our main purpose was to explore the community characteristics and dynamics conducive to project viability. Thus, we were able to construct a model that can be tested by larger-scale studies. It was also not possible to interview all participants privately. This was because of cultural expectations that one individual could not accurately speak on behalf of their community, a historically problematic assumption of Western surveying and ethnographic techniques. Rather, there was almost always one or more additional community members present during interviews and focus groups who did not speak or answer questions, but simply observed the interview process, often taking notes about the interview and the researchers. In only two interviews was it possible to gain private access to a respondent's answers; a young woman who worked an office that provided services to tourists seeking an ecotourism experience and the executive director of an NGO. Furthermore, what could be termed 
"observer effects" on responses to questions about ecotourism must be considered. Particularly in the community with a ecotourism project still in its preliminary stages, it is unclear whether the researchers' presence in the community asking about the project sparked more enthusiasm for it. Respondents answered questions as though there was no such ecotourism project, but were willing to give researchers an "ecotour" experience upon our arrival, indicating that they did in fact have some sort of project, however informal or limited in scope.

\section{Findings}

In both communities, the ecotourism projects could be characterized as community, for-profit ventures in that they were community-run projects with the goal of increasing the wealth of direct participants and of the community as a whole. Both communities also utilized the governance principles of Usos $y$ Costumbres to make community decisions and to manage their productive projects, including ecotourism and sustainable forestry. Finally, both communities utilized a workforce for their projects that was a combination of paid labor and both paid and unpaid cargos; work in the projects was distributed via Usos $y$ Costumbres.

\section{Community A}

At the time of study, Community A had about 1,000 residents and was part of a regional ecotourism collective composed of five communities located in the Sierra Norte Mountains, about a twohour bus ride from Oaxaca City. The collective received approximately 7,000 tourists a year, making it one of the largest ecotourism ventures in the state. The number of tourists has steadily increased since the collective's inception in 1996, when the community only received 20 tourists. A young woman working in the Oaxaca City office for the project described the project's inception:

Two people from Oaxaca City, who worked in ecotourism, visited the Sierra and made a proposition to talk to people in the villages and explain that ecotourism was good work. In 1996, one community developed the first project, with help from the Secretary of Tourism to establish cabins. If the tourism there was 
profitable the Secretary said he would continue with the other villages.

Funding for the initial phase of the project was provided by both the national Secretary of Tourism and a Canadian NGO. Ongoing financing for expansion of the project came from the Mexican government and from the Comisión Nacional para el Desarrollo de los Pueblos Indígenas (CDI). The CDI approves community proposals for project expansion and then provides grants to the community. Assistance and funds are also provided by the state forestry agency, Comisión Nacional Forestal.

Each community in the collective had at least five people working in ecotourism-related activities, including administrative personnel, cleaners, cooks, and guides. Three individuals coordinated activities across all five communities, and also oversaw other productive projects, such as the bottling of drinking water, preparing dried fruit, furniture-making, and sustainable forestry. The division of labor among the workers was along traditional gender lines: only two of the administrators were women, and both were in secretarial rather than leadership positions. Most of the cooks and cleaners for tourist cabins were women, and half of the guides were women. In general, recruitment to work in the ecotourism project as a paid staff member went through the cargo system. This community system provided unpaid labor for the projects, and also helped the project adjust labor supply to seasonal demands for work. However, this traditional system of community labor is becoming less popular with younger generations. The young female office worker reported:

Some [of the workers] have a salary; others work as part of cargo. In the high season, we work all day. When it's down, we take a rest. In the high season, there is full-time employment, but in the low season it is part time work...These [jobs] are cargo. The community votes on who will work them. When there's no tourism, there's no pay. But in the high season, [workers] get paid even if they started as cargo. All the guides and cleaners are local to the community they work in. Before it was all cargo, no pay. But now, some don't want to do cargo so they need the 
incentive of pay. Some like to do it; they receive cargo, but others... Yes, younger people want pay.

The rapid growth and international reputation that the involved communities have built for the project are indicators of success. The same office worker stated: "There are various [ecotourism] organizations, but ours is the most recommended." Additionally, the project appears in both international and national tourist guide books. According to the office worker, cooperation among communities is also considered an advantage: "Because there are five communities involved in the project, if tourists want a service not found in one community they can go to another. Maybe one day he wants to walk, the next to ride a horse or bicycle, no problem." The office worker also said problems within the project were often addressed communally at assemblies: "We have to work together to solve problems because we can't separate ourselves." As an example of community problem solving, another female respondent directly involved in providing tourist services in the community noted that one problem is a tree parasite that has harmed the forest, leaving many trees unhealthy. To control the spread of the plague, infected trees are burned rather than sold, so as not to spread the disease to other parts of the state.

Tourists to the community originate from Australia, Europe, the United States, and Canada, but also include domestic travelers from Mexico. Foreigners account for approximately 60 percent of the tourists. Tourists from Europe sometimes arrive in groups of 20 to 30 at a time, often based on online reservations. Such group reservations require a deposit of 50 percent, which goes directly to the community where the reservation was made. The ecotourism collective is also reaching out to other groups, as noted by the female office worker:

We are connected to almost every travel agency in Oaxaca. We are also connected to national and international travel agencies. We have ties to travel agencies in Chiapas, in other parts of Mexico, in the U.S., in France, Denmark, and the U.K. We have contacts on the coast for ecotourism in Oaxaca, but we only coordinate with other community-based organizations. 
The project uses these connections, as well as tourism guidebooks and the Internet, to attract international tourists. Services and activities include guided hikes, birding and botanical excursions, guest cabins, horseback riding, mountain biking, and annual festivals. The project aims to encourage growth of ecotourism in the area by improving services and increasing recommendations and coverage in travel guides, ultimately increasing international visibility. Interview respondents considered ecotourism a stable source of income for the community, but noted that protection from tourism's negative environmental impacts is vital to the continued success of the project. According to our female guide, "Preservation is very important... We don't want people to walk off trails because the plants' roots are established." The trails used by tourists are wellmaintained and free of litter thanks to a collective, and unpaid, effort by women of the community.

\section{Community $B$}

In contrast to Community $\mathrm{A}$, Community $\mathrm{B}$ is situated in a remote location, about a four-hour drive from Oaxaca City in the Sierra Norte Mountains. At the time of the study, Community B was still in the preliminary stages of implementing an ecotourism project. Lack of convenient accessibility by bus or from the highway due to unpaved roads necessitated private transportation by four-wheel drive vehicle. The primary productive project of this community was sustainable forestry. The ecotourism project remained in the planning stage, mainly because of the community's inaccessibility to tourists who did not know someone through which they could gain entry. Upon arrival to the town of about 1,400 inhabitants, tourists had to present themselves to the town administrators, who held their positions through cargo, and secure permission for visitation and by paying a fee. Ecotourist visits to the community occur sporadically and amount to what respondents characterized as "a few groups per year."

Community-controlled, sustainable logging began in this area in the early 1990s, after the community was able to expel an outside company that did not apply reforestation principles. This provided the opportunity to apply principles of sustainability to the logging operation, as well as to ensure that revenues generated 
through the industry stayed in the community. As one respondent explained, a man in their 50s, explained:

We have a long history. There was a big company... that logged here. No money came into the community and they did not replant. People in the community organized and expelled the company. Then we started to think about how we can create new projects that benefit our community.

Another respondent from the same community, also a man in his 50s, explained it this way:

Reforestation started 17 years ago. The community entered into organization with four other communities, Zapotecas and Chinantecas, and joined [a forestry union]. The community looked for a good union to give better treatment to the mountains. Because before there was no good treatment. The community wanted to give the mountains a better treatment.

Community goals included the expansion of forestry and ecotourism projects. Overall, the community wanted to increase productive projects to improve their economic wellbeing. Their strategy for expansion was to emulate the examples of successful projects in other communities. As part of the forestry union, they sold raw wood in Oaxaca City to a company that made pressboard. According to a middle-aged male community member, "This is a good strategy because it keeps the money in the state." In order to expand the markets for their wood and finished wood products, they built a woodworking shop, but had recently lost their only carpenter. Although their primary resource is wood, community members were aware that they were located in an area characterized by natural attractions, such as old-growth forests, cloud forests, and waterfalls. The community was considering several possible avenues for increasing ecotourism in their area, such as building cabins, improving trails, and installing a zip line near one of the waterfalls. Our male hiking guide stated:

Ecotourism is a good idea. It would bring more jobs and more animation to the community. This community has many beautiful things, so it should have ecotourism, but it's other communities that have it even though we have more attractions. 
A lot of people don't value this community enough, but it should have ecotourism above all others.

Nevertheless, community members recognized that in order to expand ecotourism, they must first establish the necessary infrastructure, such as roads, cabins, and trails, as well as organize a series of smaller projects to facilitate hosting more tourists to the area. The guide explained:

We need to advance ecotourism. We are waiting for another project to help fix the trails, but now resources are too low to cover all that we would need. Another project would help advance ecotourism, but now it is the rainy season. Reforestation makes ecotourism possible. First, we have to fix the area so that visitors have access, but first fix the paths.

To this point, while we went on a guided hike on the mountain, one of our associates fell when part of the poorly maintained trail gave way. The trail traversed virgin cloud forest and led to a preColumbian road that ran along the ridge of the mountain. Therefore, our guide felt that the first step for expanding ecotourism should be to improve the trails.

At the time of the study, Community B did not have ecotourism partnerships with other communities, but they did have permission to collect the entrance fees to the nearby national forest. The sustainable forestry union to which they belonged also included five other communities in the region. Recruitment to both the forestry and ecotourism projects was through both Usos $y$ Costumbres and cargo, and was open to anyone in the community who had time. There were seasonal variations in the labor needed for the existing logging and reforestation projects, and there were three full-time employees in the administrative office of the logging project. Because the formal ecotourism project was still in the planning stages, employment in that field was more sporadic. Both projects were funded entirely by the community through proceeds from their logging project.

Women and men were equally represented in the reforestation aspect of the sustainable logging project, but within gendered spaces. Women primarily stayed in the greenhouse, while men typically planted saplings on the mountain. Interviews with the 
women who ran the only restaurant in the community reinforced this assessment. They stated that women were responsible for the clean appearance of the community, and for gathering and preparing food. These are important contributions if the community wants to host more tourists.

The perceived successes of the productive projects in this community were related primarily to concerns for environmental wellbeing, as the guide elaborated:

Our success is the trees. The best treatment for the mountain. Not to cut everything down but to fix it. To plant back what we take... so that the resources aren't used up.

However, the logging project had not brought as many economic resources to the community as participants felt it could if expansion continued. As in Community A, tree parasites were a problem. Other challenges were that the community viewed itself as less successful than other communities, and the goals for development were unclear. Although the Mexican government provided technical advice for managing the sustainable logging project, the information was not disseminated to the entire community. Therefore, the village not only lacked the technical expertise to make pressboard within the community, but at the time of study, they also lacked a carpenter to produce finished pieces. Similarly, the community did not utilize the Internet for advertising their ecotourism venture. Community members were surprised to learn that their sustainable logging initiative had been profiled on the Internet.

The attractions offered to ecotourists included diverse ecological regions within a short distance of the community, including highland virgin and cloud forests, multiple waterfalls, sites of archeological interest, and meadows with horses. Potential activities included guided hikes, mountain biking, and horseback riding. The community had very few promotional brochures, but did have a small desk calendar featuring scenes of beauty near the community that may be visited by tourists. Community members generally had a positive view of tourism, but recognized that to be successful, they needed to expand their ecotourism project. Our guide stated: 
...we need to invest in ecotourism, to make the rooms better, construct cabins. We need restaurants, cars, T-shirts, postcards, and roads. We need to train the young people in tourism and language and as guides, to keep them here...Ecotourism is a good thing. You saw it too. It's good to start. It would be really good to start it. We will start it after the rains. When you visit next time, you'll see the improvement.

Although tourists to the community had access to sleeping accommodations, a restaurant, and a guide for hiking, accommodations had no indoor plumbing, unfinished walls, dangerous electrical wiring, and problematic access. At the time the community was not prepared to accept a large number of tourists seeking an ecotourism experience. For example, the only restaurant did not treat vegetables for possible food-borne illnesses, and thus was not prepared for international tourists. The community retained complete control of access to their location at the expense of exclusion from networks and coalitions that could be useful in establishing the project. Although the community benefited from alliances that supported their sustainable forestry project, they did not have such profitable relationships with partners for their ecotourism project.

\section{A Model for Ecotourism Viability}

Based on our research, we developed the conceptual model of ecotourism viability depicted in Figure 1 . The starting point of our model was the hypothesis that in addition to community control of projects, connectivity to other organizations and communities is essential to project viability. Successful projects ultimately facilitate sustainable development, environmental protection, and empowerment of indigenous communities. The conceptual model shows that location, available resources available infrastructure, and involvement in other projects are essential for the success of ecotourism projects. Additionally, communities need access to potential tourists, alliances with NGOs and other community networks, and external logistical and financial support. Community-initiated development projects can benefit from the expertise of NGOs, but the decision-making power must be retained by the indigenous communities in which projects unfold. There appears to be a tradeoff between community autonomy and 


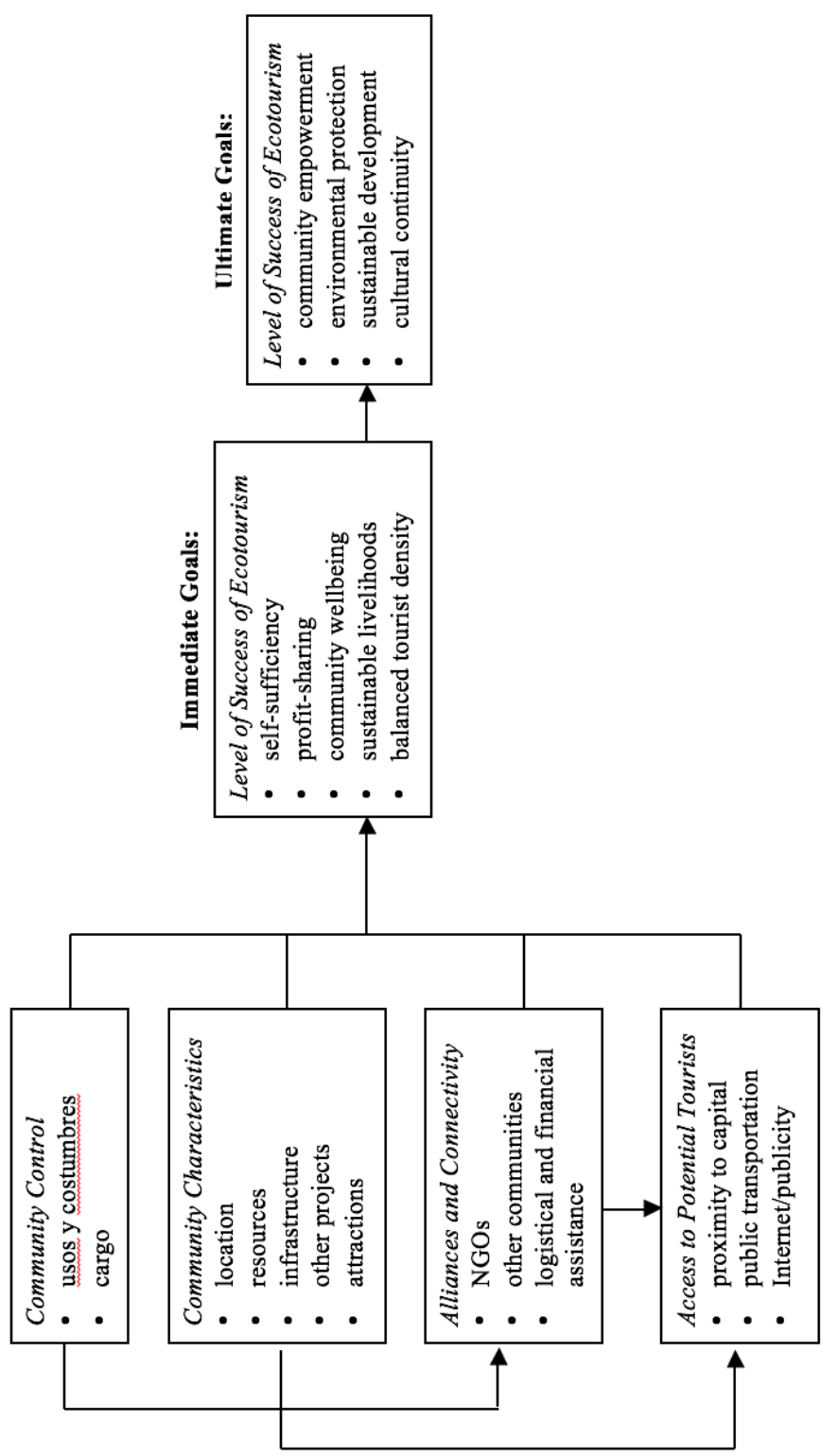

Figure 1. Conceptual Model of Ecotourism as a Sustainable Development Strategy 
the benefits associated with inclusion in the regional network of organizations and communities. Autonomy can lead to isolation and exclusion when it is not balanced with coalition-building and cooperation with partners for the purpose of generating project resources. These variables, combined with a community's own natural resources and successful land stewardship practices, including reforestation and other sustainable economic projects, determine the success of ecotourism projects, as reflected in the number of tourists, recommendations, and the overall benefit to the community. The benefits of increased economic wellbeing should be distributed equitably throughout the community, but this can be curtailed by the gendered spaces of community-based productive projects.

Productive projects, including ecotourism, encourage community members to stay in their communities rather than migrate because such projects provide jobs. The profit-sharing components and community decision-making apparatus of participatory management utilizing Usos y Costumbres help to ensure that ecotourism projects benefit the entire community in which they are located, and not simply those who directly take part in promoting or conducting tourist activities. The cargo system is also useful in initiating programs, because it allows for lower startup costs if community members are committed to the project. Ecotourism has a role to play in achieving the goals of sustainable development, but only if it is conducted in the context of other community-controlled projects that are embedded in a network of assisting local organizations. Although community control of projects remains the best mechanism to ensure that economic benefits remain with the visited community, a project's success also relates to the community's ability to balance autonomy and connectivity.

\section{Discussion and Conclusion}

This exploratory research examined how various community characteristics relate to the implementation and success of ecotourism projects in two Oaxacan communities. Of particular interest were the role of community control in terms of Usos $y$ Costumbres and cargo practices, and community connectivity to the outside, as both of these characteristics relate to the viability of 
ecotourism projects. Our research indicates that although the two communities had similar cultural practices and extensive natural resources, their ecotourism projects differed significantly.

In Community $\mathrm{A}$, participants considered ecotourism a very successful, collective project, which continued to expand every year. The community directly managed and administered the project through Usos y Costumbres and cargo, made extensive use of coalitions with other communities and organizations, and received continued governmental and NGO financial support. Specific reasons for success included the accessibility of the community from the state capital via bus lines and tourist vans, effective public relations and Internet advertising, a variety of available ecotourism activities, and continued financial support for expansion. An increasing number of annual tourists, travel agency recommendations, and features on the community in travel guides were considered signs of success by those involved in the project.

In contrast, while members in Community B would have welcomed more ecotourism, it was not yet a viable project. The project remained in the planning stages, and efforts to expand ecotourism were hampered by a lack of practical management training, minimal coalitions with other communities that had established ecotourism, and very limited financial support. Reasons for the slow progress included difficult access to the community from Oaxaca City, a lack of public relations and Internet advertising, undeveloped ecotourism activities, and a lack of appropriate accommodations. The remoteness of the community in terms of geographic inaccessibility and lack of coalitions with other communities had prevented the development of a sustainable ecotourism project. In this context, it appears that community autonomy and control translated into isolation and exclusion, which are not conducive to establishing a sustainable project.

Overall, it is not natural resources or community control that determine the success of a project, but rather a community's position within a network of other organizations that can provide assistance and experience. Resources such as transportation infrastructure to overcome remoteness, and a technical connection to the outside for public relations and advertising are necessary. Oaxacan communities governed by Usos y Costumbres and cargo are particularly well-situated to create community-controlled, 
productive projects for ecotourism because community decisionmaking mechanisms and access to low-cost labor are already in place. It appears that community control is important in the management of a project, but in order to successfully implement a project, cooperation with outside organizations is necessary.

When developing ecotourism projects, a community must protect its way of life and its natural environment, while also reaching beyond its boundaries to connect with the outside world via infrastructure and technology. Additionally, the role of grassroots NGOs and fellow communities in facilitating project development is crucial to project expansion and success. Although previous literature shows community collaboration with NGOs as problematic, the loss of community control is not inevitable. Grassroots organizations that understand and respect local conditions can encourage the use of local governing techniques to create community-initiated projects. Communities that have successfully established systems of operating their ecotourism projects can be used as models, and lead to mutually beneficial cooperations and referrals. In addition, negative tourist impact can be mitigated by community control. For example, the number of cabins a community decides to construct limits the number of tourists to the area.

Future research into how Oaxacan community decision-making processes affect ecotourism projects should seek to observe the assemblies where key decisions are made. We had to rely on participants' accounts of how such decision-making practices are conducted because outsiders have no access to assemblies. Interestingly, we found that the role of women in the projects appears important, but is not always visible or credited. It seems that women are less involved with decisions made at governing assemblies and project leadership, but have important roles in performing cargo. Future research should explore the gender dimension of ecotourism project management and success.

We hope that researchers and practitioners interested in improving the viability of projects geared toward sustainable livelihoods in indigenous communities find our model useful. We believe the model can guide grassroots efforts to find a balance between community autonomy and network integration based on local needs and conditions. We refrain from making specific 
recommendations because our results are based on a small exploratory study, and each community faces a unique constellation of conditions. Ultimately, community members must make informed decisions about how to proceed with projects based on their own needs, visions, and available resources. A larger-scale study would be conducive to developing key guidelines and suggestions for struggling communities. 


\section{References}

Adler, M. 2012. "The Role of Grassroots Organizations in the Promotion of Sustainable Indigenous Communities in Mexico." International Journal of Humanities and Social Science 2:235-248.

Antinori, C. and G. Rausser. 2006. "Collective Choice and Community Forestry Management in Mexico: An Empirical Analysis." Journal of Development Studies 43:512-536. Bacon, D. 2004. Children of NAFTA: Labor Wars on the U.S./Mexico Border. Berkeley, CA: University of California Press.

Cater, Erlet. 1994. "Ecotourism in the Third-World: Problems and Prospects for Sustainability." Pp. 69-86 in Ecotourism: A Sustainable Option?, edited by E. Carter and G. Lowman. New York, NY: Wiley.

Ceballos-Lascuráin, H. 1996. Tourism, Ecotourism, and Protected Areas: The State of Nature-Based Tourism around the World and Guidelines for its Development. Cambridge, UK: IUCN.

Cerina, F. 2008. "Tourism, Growth, and Pollution Abatement." Pp. 3-27 in Tourism and Sustainable Economic Development: Macroeconomic Models and Empirical Methods, edited by R. Brau, A. Lanza, and S. Usai. Northampton, MA: Edward Elgar Publishing Limited.

Champagne, D. 2010. Notes from the Center of Turtle Island. Lanham, MD: AltaMira Press.

De Frece, A. and N. Poole. 2008. "Constructing Livelihoods in Rural Mexico: Milpa in Mayan culture.” The Journal of Peasant Studies 35:335-352.

Esteva, G. 2006. "Interview with Gustavo Esteva: The Society of the Different Part 2. We Are People of Corn: Life, Metaphor, Autonomy." Motion Magazine, April 2006. Retrieved May 15, 2011

(http://www.inmotionmagazine.com/global/gest_int_2.html).

Fox, J. 2007. "Rural Democratization and Decentralization at the State/Society Interface: What Counts as 'Local' Government in the Mexican Countryside?" The Journal of Peasant Studies 34:527-559. 
Holt-Gimenez, E. 2006. Campesino a Campesino: Voices from Latin America's Farmer to Farmer Movement for Sustainable Agriculture. Oakland, CA: Food First Books.

Gössling, S., C. M. Hall, and D. B. Weaver. 2009. Sustainable Tourism Futures: Perspectives on Systems, Restructuring and Innovations. New York, NY: Routledge.

Honey, M. 2008. Ecotourism and Sustainable Development: Who Owns Paradise? 2nd ed. Washington, DC: Island Press.

Instituto Nacional de Estadística y Geografía (INEGI). 2005a. Información de su Entidad Federativa: Oaxaca: Territorio, Población, Económica. Oaxaca City, Mexico.

Instituto Nacional de Estadística y Geografía (INEGI). 2005b.

“Conteo de Población y Vivienda 2005." Retrieved August 16, 2009

(http://www.inegi.org.mx/sistemas/consulta_resultados/iter200 5.aspx? $=27436 \& s=e s t)$.

Mawdsley, E., J. Townsend, G. Porter, and P. Oakley. 2002. Knowledge, Power and Development Agendas: NGOs North and South. Oxford, UK: INTRAC.

Momsen, J. H. 2002. "NGOs, Gender and Indigenous Grassroots Development." Journal of International Development 14:859867.

Place, S. E. 1998. "How Sustainable is Ecotourism in Costa Rica?" Pp. 107-118 in Sustainable Tourism: A Geographical Perspective, edited by C. M. Hall and A. A. Lew. Essex, UK: Addison Wesley Longman Limited.

Rinzin, C., W. J. V. Vermeulen, and P. Glassbergen. 2007.

"Ecotourism as a Mechanism for Sustainable Development:

The Case of Bhutan." Environmental Sciences 4:109-125.

Ritchie, J. R. B. and G. I. Crouch. 2003. The Competitive Destination: A Sustainable Tourism Perspective. Cambridge, MA: CABI.

Roberts, S. M., J. P. Jones III, and O. Froehling. 2005. "NGOs and the Globalization of Managerialism: A Research Framework." World Development 33:1845-1864. 
Stronza, A. 2008. "The Bold Agenda of Ecotourism." Pp. 3-17 in Ecotourism and Conservation in the Americas, edited by $\mathrm{A}$. Stronza and W. H. Durham. Cambridge, MA: CABI.

United Nations. 1992. "Report of the United Nations Conference on Environment and Development, Rio de Janeiro." Retrieved December 15, 2010

(http://www.un.org/documents/ga/conf151/aconf151263annex3.htm).

World Commission on Environment and Development (WCED). 1987. Our Common Future. Oxford, UK: Oxford University Press.

World Ecotourism Summit: Québec City, Canada. 2002. "The Québec Declaration on Ecotourism.” Retrieved December 30, 2010

(http://www.unep.fr/shared/publications/pdf/WEBx0078xPAEcotourismSummitEN.pdf).

Yang, L. 2011. "Ethnic Tourism and Cultural Representations." Annals of Tourism Research 38:561-585.

Zeppel, H. 1998. "Land and Culture: Sustainable Tourism and Indigenous Peoples." Pp. 60-74 in Sustainable Tourism: A Geographical Perspective, edited by C. M. Hall and A. A. Lew. Essex, UK: Addison Wesley Longman Limited.

Zeppel, H. 2006. Indigenous Ecotourism: Sustainable Development and Management. Cambridge, UK: CABI. 